\title{
PENGARUH SELF-ESTEEM DAN SELF-AWARENESS TERHADAP PENGELOLAAN UANG SAKU
}

\author{
Sindi Nur Alfilail ${ }^{1}$, Rendika Vhalery ${ }^{2(*)}$ \\ Universitas Indraprasta PGRI Jakarta, Indonesia \\ Sindi.alfilail@gmail.com ${ }^{1}$, rendika.vhalery@unindra.ac.id
}

Received: 24 Maret 2020

Revised: 25 Maret 2020

\begin{abstract}
Uang saku semakin menarik untuk dikaji ketika sisi psikologis terlibat didalamnya. Ada banyak variabel dalam sisi psikologis yang menarik untuk dikaji. Sisi psikologis yang terlibat pada penelitian kali ini yaitu selfesteem sebagai rasa harga diri pada pengelolaan uang saku dan selfawareness sebagai rasa kesadaran diri pada pengelolaan uang saku. Penelitian ini bertujuan untuk mengetahui apakah self-esteem dan selfawareness berpengaruh pada pengelolaan uang saku. Penelitian ini dilakukan pada bulan mei sampai bulan juli 2019. Penelitian dilakukan di Universitas Indraprasta PGRI Jakarta yang melibatkan 144 mahasiswa. Pengumpulan data penelitian menggunakan angket/kuesioner yang mengukur indikator tiap variabel pada instrument penelitian. Instrument penelitian di uji validitas dan di uji reiabilitas untuk mengetahui ke-validan instrumen dan dapat di percaya. Data di analisis menggunakan uji normalitas data, uji homogenitas data, dan uji regresi linear berganda. Hasil menunjukkan bahwa self-esteem berpengaruh signifikan terhadap pengelolaan uang saku, self-awareness berpengaruh signifikan terhadap pengelolaan uang saku, dan self-esteem dan self-awareness berpengaruh signifikan terhadap pengelolaan uang saku
\end{abstract}

Keywords: Self-Esteem, Self-Awareness, Pengelolaan, Uang Saku

(*) Corresponding Author: $\quad$ Rendika Vhalery, rendikavhalery31@gmail.com, 081271777755

How to Cite: Alfilail, S. N., \& Vhalery, R. (2020). Pengaruh Self-Esteem Dan Self-Awareness Terhadap Pengelolaan Uang Saku. Research and Development Journal of Education, 6(2), 38-48.

\section{INTRODUCTION}

Uang saku adalah sejumlah uang diberikan setiap minggu, bulan, atau tahun. Vhalery, Leksono, dan Irvan (2019) menambahkan bahwa uang saku diberikan orang tua kepada anaknya untuk keperluan pribadi dan pendidikan. Uang saku dianggap sebagai motivator perilaku yang paling kuat dalam hal pemuas kebutuhan (Hanley dan Wilhelm, 1992). Tidak hanya kebutuhan, keinginan akan barang atau jasa setiap individu selalu berubah dari waktu ke waktu dan cenderung bertambah banyak. Sina dan Noya (2012) menyatakan bahwa sumber daya uang saku yang terbatas bertolak belakang dengan keinginan dan kebutuhan setiap orang yang relative tidak terbatas. Oleh karena itu, dibutuhkan pengelolaan uang saku seperti aktivitas perencanaan uang masuk, uang keluar, dan pengendalian uang saku (Vhalery, Aimon, dan Yulhendri, 2018).

Menurut Marteniawati, Risvina (2012) pengelolaan uang saku adalah upaya seseorang dalam mengatur uang saku yang diterima dari orang tua untuk memenuhi keperluan tambahan pribadi. Griffin, (2006) mengemukakan bahwa pengelolaan uang saku adalah cara penggunaan uang saku secara efektif dan efisien. Pengelolaan uang saku berhubungan dengan kesadaran diri seseorang dalam menggunakan uang tambahan untuk memenuhi kebutuhan pribadi serta dalam upaya peningkatan harga diri. Namun, kenyataannya banyak individu yang kurang maksimal dalam pengelolaan uang saku. 
Akibatnya, mereka menjadi pribadi yang tidak terkontrol dalam pemenuhan kebutuhan dan keinginan.

Berdasarkan hasil observasi dilapangan, beberapa individu sadar ketika menggunakan uang saku untuk memenuhi kebutuhan sehari-hari terutama diluar rumah. Beberapa individu mengalokasikan uang sakunya untuk ditabung. Disisi lain, ada individu yang kurang maksimal dalam mengelola uang saku dengan baik, seperti menggunakan uang saku sesuai keinginannya secara berlebihan. Contohnya, individu yang menggunakan uang sakunya untuk membeli makanan, dia tidak perduli dengan hal lain kecuali tentang makanan. Ada juga individu yang menggunakan uang sakunya untuk kegiatan-kegiatan sosialitas dan lainnya. Secara garis besar, kebanyakan individu mengetahui apa yang diinginkan bukan apa yang dibutuhkan. Bahkan, ada individu yang benar-benar tidak mengetahui bagaimana cara mengelola uang saku.

Untuk mengetahui lebih lanjut, peneliti melakukan wawancara kepada beberapa mahasiswa mengenai pengelolaan uang saku. Berdasarkan hasil wawancara, diketahui bahwa mahasiswa lebih dominan menggunakan uang saku untuk keinginan daripada kebutuhan sehari-hari. Selain itu, ada juga yang menggunakan uang saku berlebihan hanya untuk memenuhi gaya hidup. Hal ini menunjukkan bahwa perilaku mahasiswa dalam menggunakan dan mengelola uang saku masih sangat memprihatinkan. Dikhawatirkan akan terus berlanjut dan berdampak buruk untuk dirinya dimasa mendatang.

Pengelolaan uang saku dipengaruhi oleh faktor psikologi atau internal individu (Nidar, 2012). Hanley and Wilhelm (1992) mengemukakan bahwa faktor internal yang mempengaruhi pengelolaan uang saku yaitu self-esteem (harga diri). Harga diri adalah sikap yang menguntungkan atau tidak menguntungkan terhadap diri seseorang (Rosenberg, 1965). Sedangkan Clemes (1995) menyatakan bahwa harga diri adalah nilai diri individu yang berlandaskan pengalaman sebagai dasar pertumbuhan positif dalam tanggung jawab kepribadian. Mark Manson (2018) menambahkan kesadaran diri adalah pemahan yang sederhana terhadap keadaan seseorang. Lebih lanjut, Juneman (2012) mengungkapkan bahwa uang dapat meningkatkan harga diri seseorang. Contohnya, gaji tinggi yang diterima karyawan memiliki implikasi positif menuju citra diri, karena gaji melambangkan atau membuktikan kompetensinya. Uang dan harga diri juga dapat memberi kompensasi satu sama lain untuk mendapatkan kepuasan hidup (efek substitusi). Disisi lain, harga diri yang rendah dapat mempengaruhi seseorang untuk melakukan tindakan keuangan yang tidak wajar (Clemes, 1995). Hal ini disebabkan karena kurang efektifnya pengelolaan uang saku yang dapat menyebabkan kekeliruan dalam mengelola uang saku jangka panjang (Kiyosaki, 2009). Contohnya, banyak orang yang tidak mampu mengontrol uang dengan baik hanya karena memenuhi keinginannya untuk dapat bersaing dengan orang lain sehingga timbulah perilaku keuangan yang berlebihan. Oleh karena itu, harga diri seseorang dalam mengelola uang saku menjadi salah satu faktor penting yang perlu ditindak lanjut (Cummins, 2009).

Selain self-esteem (harga diri), self-awareness (kesadaran diri) juga berpengaruh terhadap pengelolaan uang saku. Taubman Ben-Ari, Florian, \& Mikulincer, (1999) mengatakan bahwa kesadaran diri merupakan komponen terbaik untuk mendokumentasikan sejauh mana uang dapat bertindak. Zhou et al., (2009) menambahkan bahwa indivu yang berhadapan dengan uang secara langsung merasa lebih kuat daripada individu yang berhadapan dengan uang secara tidak langsung (dari sisi perasaan, kesadaran, dan harga diri). Kesadaran diri diperlukan dalam pengelolaan uang untuk menetapkan batas-batas yang diperlukan dalam penggunaan uang. Diener dan Biswas-Diener (2002) mengemukakan bahwa kesadaran diri terhadap uang akan berpengaruh pada kebahagiaan seseorang. Tinjauan kebahagiaan merujuk pada kepuasan 
hidup dan kesejahteraan subjektif serta kualitas hidup (Camfield, 2006; Ng, 2015). Secara sederhana, kesadaran diri menentukan kebahagiaan finansial seseorang.

Banyak orang yang mengetahui tentang uang, namun tidak banyak orang yang paham bagaimana cara mengelola uang lebih efektif. Terkadang orang menggunakan uang untuk meningkatkan harga diri tanpa disertai dengan kesadaran diri. Secara sederhana, kesadaran diri merupakan tanggung jawab secara pribadi atas pengelolaan uang saku dalam hidup. Dan penelitian uang saku dapat dikategorikan masih sedikit. Oleh sebab itu, peneliti tertarik untuk melakukan penelitian dengan judul "pengaruh selfesteem dan self-awareness terhadap pengelolaan uang saku". Hipotesis yang diajukan yaitu $\mathrm{H}_{1}$ : Terdapat pengaruh self-esteem terhadap pengelolaan uang saku, $\mathrm{H}_{2}$ : Terdapat pengaruh self-awareness terhadap pengelolaan uang saku, dan $\mathrm{H}_{3}$ : Terdapat pengaruh self-esteem dan self-awareness terhadap pengelolaan uang saku.

\section{METHODS}

Penelitian ini dilakukan di Universitas Indraprasta PGRI Jakarta pada bulan Mei - Juli 2019. Populasi dalam penelitian ini adalah mahasiswa pendidikan ekonomi Universitas Indraprasta PGRI Jakarta. Tipe sampel menggunakan non-probability sampling. Teknik sampling menggunakan accindetal Sampling yaitu sampel yang menggunakan responden yang dapat ditemuin pada saat melakukan penelitian, atau partisipan yang mau menjadi sampel penelitian. Jumlah partisipan dalam sampel penelitian ini yaitu sebanyak 144 mahasiswa pendidikan ekonomi Universitas Indraprasta PGRI. Teknik pengumpulan data yaitu kuesioner (angket) menggunakan skala ordinal yang mengacu pada skala penilaian sikap (likert). Instrument penelitian dapat dilihat pada tabe berikut ini:

Tabel 1.

Instrument Penelitian

\begin{tabular}{|c|c|c|c|}
\hline No. & Variabel & Indikator & $\begin{array}{c}\text { Skala } \\
\text { Pengukuran }\end{array}$ \\
\hline 1 & Self-Esteem & $\begin{array}{l}\text { a. Menganggap dirinya berharga } \\
\text { b. Mengahargai orang lain } \\
\text { c. Mengontrol diri } \\
\text { d. Menerima kritik } \\
\text { e. Menyukai tantangan } \\
\text { f. Mengekspresikan diri } \\
\text { g. Mengetahui keterbatasan diri } \\
\text { h. Memiliki nilai dan sikap demokratis } \\
\text { serta realistis } \\
\text { i. Hidup efektif } \\
\text { (Ismi dan Mukhlis, 2013) }\end{array}$ & Skala Ordinal \\
\hline 2 & Self-Awareness & $\begin{array}{l}\text { a. Attention } \\
\text { b. Wakefulness } \\
\text { c. Architecture } \\
\text { d. Recall of knowledge } \\
\text { e. Self knowledge } \\
\quad \text { (Maharani dan Meri, 2016) }\end{array}$ & Skala Ordinal \\
\hline 3 & $\begin{array}{c}\text { Pengelolaan } \\
\text { uang saku }\end{array}$ & $\begin{array}{l}\text { a. Pengelolaan Uang Masuk } \\
\text { b. Pengelolaan Uang Keluar } \\
\text { c. Dana Simpanan } \\
\text { (Vhalery, Aimon, H. \& Yulhendri, 2019) }\end{array}$ & Skala Ordinal \\
\hline
\end{tabular}

Sumber : Peneliti 2019 
Sebelum disebarkan kepada responden, kuesioner diuji cobakan kepada responden yang bukan subjek penelitian untuk mengetahui kelayakan kuesioner. Lalu, kuesioner di uji validitas dan di uji reliabilitas. Hasil uji coba kuesioner dapat dilihat pada bagian lampiran dibawah. Setelah kuesioner valid dan reliabel, maka kuesioner disebarkan kepada responden. Teknik analisis data menggunakan bantuan software SPSS 24.0. for windows.

\section{RESULTS \& DISCUSSION}

\section{Results}

Pada tahap awal dilakukan uji normalitas data. Uji normalitas data dapat juga dikatakan sebagai uji prasyarat atau uji asumsi klasik. Uji normalitas data digunakan untuk mengetahui apakah data penelitian bersifat normal atau bersifat tidak normal. Apabila data bersifat normal maka dilakukan uji statistik parametrik dan apabila data bersifat tidak normal maka dilakukan uji statistik non-parametrik. Uji normalitas pada penelitian ini menggunakan rumus Kolmogorov-smirnov. Adapun ketentuan penggunaan uji normalitas data menggunakan rumus kolmogorov-smirnov berbantuan SPSS 24.0 for windows. Apabila nilai Asymp. Sig. (2-tailed) pada kolmogorov-smirnov >0,050 maka data bersifat normal. Apabila nilai Asymp. Sig. (2-tailed) pada kolmogorov-smirnov < 0,050 maka data bersifat tidak normal. Hasil uji normalitas data dapat dilihat pada tabel berikut ini:

Tabel 2.

Uji Normalitas Data

\begin{tabular}{|c|c|c|c|c|}
\hline & & Pengelolaan Uang Saku & Self-Esteem & Self-Awareness \\
\hline $\mathbf{N}$ & & 144 & 144 & 144 \\
\hline \multirow[t]{2}{*}{ Normal Parameters } & Mean & 49,43 & 93,01 & 59,10 \\
\hline & Std. Deviation & 10,508 & 14,180 & 9,268 \\
\hline \multirow[t]{3}{*}{ Most Extreme Differences } & Absolute &, 073 &, 070 &, 050 \\
\hline & Positive &, 069 &, 070 &, 050 \\
\hline & Negative &,- 073 &,- 059 &,- 043 \\
\hline Test Statistic & &, 073 &, 070 &, 050 \\
\hline Asymp. Sig. (2-tailed) & &, 060 &, 084 & ,200 \\
\hline Kesimpulan & & Normal & Normal & Normal \\
\hline
\end{tabular}

Berdasarkan hasil output SPSS pada tabel 2 diketahui bahwa nilai Asymp. Sig. (2-tailed) pada rumus Kolmogorov-Smirnov diatas 0,050. Disimpulkan bahwa data penelitian dari variabel pengelolaan uang saku, variabel self-esteem, dan variabel selfawareness bersifat normal. Data dapat dilanjutkan pengujian berikutnya. Pengujian berikutnya yaitu uji homogenitas data.

Uji Homogenitas data digunakan untuk mengetahui apakah data penelitian bersifat homogen / sama atau bersifat tidak homogen / tidak sama. Uji homogenitas pada penelitian ini menggunakan uji Lavene. Adapun ketentuan penggunaan uji homogenitas data menggunakan rumus Lavene berbantuan SPSS 24.0 for windows. Apabila nilai Sig. uji lavene $>$ 0,050 maka data bersifat homogen. Apabila nilai Sig. uji lavene < 0,050 
maka data bersifat tidak homogen. Hasil uji homogenitas data dapat dilihat pada tabel berikut ini:

Tabel 3.

Uji Homogenitas Data

\begin{tabular}{lccccc|c}
\hline Pengelolaan Uang Saku Pada & Levene Statistic & df1 & df2 & Sig. & Kesimpulan \\
\hline Self- Esteem & 1,428 & 31 & 106 &, 093 & Homogen \\
Self-Awareness &, 981 & 29 & 105 &, 503 & Homogen \\
\hline
\end{tabular}

Sumber: Data Olahan SPSS 24.0 Peneliti Tahun 2019

Berdasarkan hasil output SPSS pada tabel 3 diketahui bahwa nilai Sig. uji lavene diatas 0,050. Disimpulkan bahwa data penelitian dari variabel pengelolaan uang saku, variabel self-esteem, dan variabel self-awareness bersifat homogen. Data dapat dilanjutkan pengujian berikutnya. Pengujian berikutnya yaitu pengujian hipotesis menggunakan uji regresi linear berganda.

Pengujian hipotesis menggunakan ketentuan, apabila nilai $t_{\text {hitung }}>t_{\text {tabel }}$ maka hipotesis diterima dan apabila apabila nilai $t_{\text {hitung }}<t_{\text {tabel }}$ maka hipotesis ditolak. Selain itu, apabila nilai $\mathrm{F}_{\text {hitung }}>\mathrm{F}_{\text {tabel }}$ maka hipotesis diterima dan apabila apabila nilai $\mathrm{F}_{\text {hitung }}<\mathrm{F}_{\text {tabel }}$ maka hipotesis ditolak. Untuk signifikansi, apabila nilai sig $<0,050$ maka signifikan dan apabila apabila nilai sig $>0,050$ maka tidak signifikan. Hasil uji hipotesis dapat dilihat pada tabel berikut ini:

Tabel 4.

Uji Regresi Linear Berganda

\begin{tabular}{|c|c|c|c|c|c|}
\hline \multirow[t]{2}{*}{ Model } & \multicolumn{2}{|c|}{$\begin{array}{l}\text { Unstandardized } \\
\text { Coefficients }\end{array}$} & \multirow{2}{*}{$\begin{array}{c}\begin{array}{c}\text { Standardized } \\
\text { Coefficients }\end{array} \\
\text { Beta }\end{array}$} & \multirow[t]{2}{*}{$\mathbf{T}$} & \multirow[t]{2}{*}{ Sig. } \\
\hline & $\mathbf{B}$ & Std. Error & & & \\
\hline (Constant) & 22,611 & 7,777 & & 2,907 & ,004 \\
\hline Self-Esteem &, 172 &, 060 & ,233 & 2,879 &, 005 \\
\hline Self-Awareness &, 183 & ,092 & , 161 & 1,995 &, 048 \\
\hline $\mathrm{F}$ & \multicolumn{5}{|c|}{6,181} \\
\hline F-Sig. & \multicolumn{5}{|c|}{,003 } \\
\hline $\mathrm{R}$ & \multicolumn{5}{|c|}{,284 } \\
\hline R Square & \multicolumn{5}{|c|}{081} \\
\hline Adjusted R Square & \multicolumn{5}{|c|}{, 068} \\
\hline $\begin{array}{l}\text { Std. Error of the } \\
\text { Estimate }\end{array}$ & \multicolumn{5}{|c|}{10,147} \\
\hline
\end{tabular}

Dependent Variable: Pengelolaan Uang Saku

Sumber: Data Olahan SPSS 24.0 Peneliti Tahun 2019

Berdasarkan hasil output SPSS pada tabel 4 diketahui nilai $Y=a+b_{1} X_{1}+b_{2} X_{2}$ sebesar $\mathrm{Y}=22,611+0,172+0,183$. Dari nilai adjusted $R$ square didapat nilai 0,068 atau $6,8 \%$. Artinya, kontribusi penelitian dari variabel self-esteem dan self-awarenss terhadap pengelolaan uang saku sebesar $6,8 \%$, sedangkan $93,2 \%$ kontribusi dari variabel yang tidak diteliti. $t_{\text {tabel }}$ pada penelitian ini sebesar 1,977 dan $F_{\text {tabel }}$ pada penelitian ini sebesar 2,667. Dari tabel 4 juga diketahui bahwa :

1) Hasil $t_{\text {hitung }}$ variabel self-esteem sebesar $2,879>t_{\text {tabel }} 1,977$ maka hipotesis pertama diterima. Nilai signifikan sebesar $0,005<0,050$, yang berarti signifikan. Artinya, terdapat pengaruh signifikan self-esteem terhadap pengelolaan uang saku.

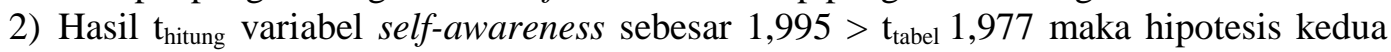
diterima. Nilai signifikan sebesar 0,048 $<0,050$, yang berarti signifikan. Artinya, terdapat pengaruh signifikan self-awareness terhadap pengelolaan uang saku. 
3) Hasil $F_{\text {hitung }}$ variabel self-esteem sebesar 6,181 > $F_{\text {tabel }}$ 2,667 maka hipotesis ketiga diterima. Nilai signifikan sebesar $0,003<0,050$, yang berarti signifikan. Artinya, terdapat pengaruh signifikan self-esteem dan self-awareness terhadap pengelolaan uang saku.

\section{Discussion}

1. Pengaruh self-esteem terhadap pengelolaan uang saku

Hasil penelitian menunjukkan bahwa self-esteem berpengaruh signifikan terhadap pengelolaan uang saku. self esteem dibutuhkan masyarakat untuk memanfaatkan perilaku mengelola keuangan yang ia miliki agar dapat mempertahankan harga diri (Hilma,2018). Remaja dengan tingkat harga diri yang tinggi merasa lebih kompeten dan sanggup untuk membantu orang lain yang membutuhkan daripada remaja dengan harga diri rendah karena kebutuhan mereka sendiri sudah terpenuhi (Riska, 2018).

2. Pengaruh self-awareness terhadap pengelolaan uang saku

Hasil penelitian menunjukkan bahwa self-awareness berpengaruh signifikan terhadap pengelolaan uang saku. Kesadaran diri untuk meningkatkan kemampuan mengelola uang pribadi dengan tepat atau bijak (Sina, 2012). Mahasiswa yang memiliki pengelolaan uang saku dan ditambah dengan kontrol diri yang baik, maka mereka mampu mengelola uang sakunya dengan baik dan didukung oleh kontrol diri yang baik pula (Lutfiah, 2015). Dengan demikian, dapat dikatakan bahwa kesadaran diri (self-awareness) memberi pengaruh terhadap kepuasan hidup dalam diri seseorang (Dariyo, 2016).

\section{Pengaruh self-esteem dan self-awareness terhadap pengelolaan uang saku}

Dari hasil penelitian menunjukkan bahwa self-esteem dan self-awareness berpengaruh signifikan terhadap pengelolaan uang saku. Sina (2012) menambahkan Harga diri dan kesadaran diri yang dimaksud, bagaimana seseorang meningkatkan pemahaman keuangan sehingga secara kontinu dapat memahami perubahan dalam keuangan serta mampu menentukan keputusan keuangan dengan tepat. Dengan demikian, agar pemanfatan sumberdaya uang mencapai optimum diperlukan usaha manajemen keuangan yang baik dan efektif.

\section{CONCLUSION}

Berdasarkan hasil dan pembahasan dapat disimpulkan bahwa; 1) terdapat pengaruh self-esteem terhadap pengelolaan uang saku secara signifikan, 2) terdapat pengaruh self-awareness terhadap pengelolaan uang saku secara signifikan, 3) terdapat pengaruh self-esteem dan self-awareness terhadap pengelolaan uang saku secara signifikan. Adapun saran yang dapat diberikan yaitu; 1) untuk peneliti selanjutnya diharapkan dapat menggunakan indikator lain untuk menambah khasanah ilmu pengetahuan, 2) diharapkan menggunakan variabel lain atau membandingankan variabel ini dengan variabel psikologis lainnya, 3) hasil penelitian ini diharapkan dapat menjadi rujukan siswa, mahasiswa, orang tua atau bahkan masyarakat luas. 


\section{REFERENCES}

Chitchai, N., Senasu, K., \& Sakworawich, A. (2018). The moderating effect of love of money on relationship between socioeconomic status and happiness. Kasetsart Journal of Social Sciences.

Cummins M., Haskel J. H., \& Jenkins S. 2009. "Financial Attitudes And Spanding Habits Of University Fresmen". Journal Of Economics And Economic Education Research. Vol. 10 (1) : pp. 3-6.

Gasiorowska, A., Zaleskiewicz, T., \& Kesebir, P. (2018). Money as an existential anxiety buffer: Exposure to money prevents mortality reminders from leading to increased death thoughts. Journal of Experimental Social Psychology.

Dariyo, A. (2016). Peran Self-Awareness dan Ego Support terhadap Kepuasan Hidup Remaja Tionghoa. PSIKODIMENSIA, 15(2), 254-274.

Halafir, E., \& Linardi, S. (2016). Awareness of Low Self-Control: Theory and Evidence. Available at SSRN 2758914.

Hanley, A., \& Wilhelm, M. S. (1992). Compulsive buying: An exploration into selfesteem and money attitudes. Journal of economic Psychology, 13(1), 5-18.

Hilma, F. (2018). Analisis Pengaruh Self Esteem, Money Belief, Spending Habits Dan Financial Knowledge Terhadap Financial Management Behavior Pada Masyarakat Muda Dewasa Belum Menikah Di Kota Padang (Doctoral Dissertation, Universitas Andalas).

Incekara-Hafalir, E., \& Linardi, S. (2017). Awareness of low self-control: Theory and evidence from a homeless shelter. Journal of Economic Psychology, 61, 39-54.

Kamila, I. I., \& Mukhlis, M. (2013). Perbedaan harga diri (self esteem) remaja ditinjau dari keberadaan ayah. Jurnal psikologi, 9(2), 100-112.

Lutfiah, U., \& Soesilo, Y. H. (2015). Pengaruh jumlah uang saku dan kontrol diri terhadap pola konsumsi mahasiswa Jurusan Ekonomi Pembangunan Fakultas Ekonomi Universitas Negeri Malang. Jurnal Pendidikan Ekonomi (Economic Education Journal), 8(1).

Leksono, A. W., \& Vhalery, R. (2019). Pengaruh Self-Knowledge Dan Self-Deception Terhadap Pengelolaan Uang Saku. Research and Development Journal of Education, 6(1), 28-40.

Maharani, L., \& Mustika, M. (2016). Hubungan Self Awareness dengan Kedisiplinan Peserta Didik Kelas VIII di SMP Wiyatama Bandar Lampung (Penelitian Korelasional Bidang Bk Pribadi). KONSELI: Jurnal Bimbingan dan Konseling (E-Journal), 3(1), 57-62.

Marteniawati, Risvina. (2012). Mental Accounting Dalam Pengelolaan Uang Saku.Universitas Kristen Satya Wacana: Salatiga.

Mulyadi, S., \& Trizki, L. (2012). Financial Parenting: Menjadikan Anak Cerdas dan Cermat Mengelola Uang. Noura Books.

Meinarno, E. A., \& Rahardjo, W. (2012). Symbolic meaning of money, self-esteem, and identification with Pancasila values. Procedia-Social and Behavioral Sciences, 65, 106-115.

Riska, H. A., Krisnatuti, D., \& Yuliati, L. N. (2018). Pengaruh Interaksi Remaja dengan Keluarga dan Teman serta Self-Esteem terhadap Perilaku Prososial Remaja Awal. Jurnal Ilmu Keluarga \& Konsumen, 11(3), 206-218.

Roberts, J. A., Manolis, C., \& Tanner, J. F. J. (2003). Family structure, materialism, and compulsive buying: A reinquiry and extension. Journal of the Academy of Marketing Science, 31(3), 300-311.

Sina, P. G., \&Noya, A. (2012). Pengaruh Kecerdasan Spiritual Terhadap Pengelolaan Keuangan Pribadi. JurnalManajemen Maranatha, 11(2). 
Vhalery, R., Aimon, H., \& Yulhendri, Y. (2018). The Management of Student's Pocket Money.

Vhalery, R., Leksono, A. W., \& Irvan, M. (2019). Pengaruh Literasi Keuangan, Usia, dan Bimbingan Orang Tua terhadap Pengelolaan Uang Saku Mahasiswa UNINDRA. Jurnal Pendidikan Ekonomi, 12(1), 10-17.

Wardhani, M. D. (2009). Hubungan antara konformitas dan harga diri dengan perilaku konsumtif pada remja putri. Universitas Sebelas Maret: Surakarta.

Whillans, A. V., \& Dunn, E. W. (2015). Thinking about time as money decreases environmental behavior. Organizational Behavior and Human Decision Processes, 127, 44-52. 


\section{APPENDIX}

\section{Hasil Uji Validitas dan Uji Reliabilitas}

\section{Pengelolaan Uang Saku}

\begin{tabular}{|c|c|c|c|c|c|}
\hline No. & Pernyataan & Pearson Correlation & Sig. (2-tailed) & Validitas & Reliabilitas \\
\hline 1. & Saya mencatat uang saku yang saya terima & $.456^{* *}$ & 0.008 & Valid & \\
\hline 2. & Saya membuat laporan uang saku secara sederhana & $.488^{* *}$ & 0.004 & Valid & \\
\hline 3. & Saya memiliki rencana keuangan untuk kedepan & $.626^{* *}$ & 0.000 & Valid & \\
\hline 4. & Saya mematuhi rencana keuangan yang telah saya buat & $.623^{* *}$ & 0.000 & Valid & \\
\hline 5 . & Saya membuat tujuan uang saku yang harus dicapai & $.654^{* *}$ & 0.000 & Valid & \\
\hline 6. & Saya membuat daftar kebutuhan yang akan dibeli & $.623^{* *}$ & 0.000 & Valid & \\
\hline 7. & Saya membuat daftar belanja mingguan/bulanan & $.544^{* *}$ & 0.001 & Valid & \\
\hline 8. & Saya mengikuti anggaran belanja yang telah saya buat & $.705^{* *}$ & 0.000 & Valid & \\
\hline 9. & Saya menggunakan uang saku seefisien mungkin & $.356^{*}$ & 0.042 & Valid & \\
\hline 10. & Saya menggunakan sebagian uang untuk keperluan sekolah/kampus & $.395^{*}$ & 0.023 & Valid & Reliabel \\
\hline 11. & Saya mencatat semua biaya pengeluaran & $.391^{*}$ & 0.025 & Valid & \\
\hline 12. & Ketika berbelanja saya hanya berbelanja yang saya butuhkan & $.539^{* *}$ & 0.001 & Valid & \\
\hline 13. & Saya membelanjakan uang diakhir periode sampai habis & -0.095 & 0.598 & Tidak Valid & \\
\hline 14. & Ketika berbelanja saya mendahulukan keinginan daripada kebutuhan & -0.048 & 0.792 & Tidak Valid & \\
\hline 15 . & Saya menyisihkan sebagian uang saku untuk hal-hal yang tidak terduga & $.448^{* *}$ & 0.009 & Valid & \\
\hline 16. & Saya memiliki rekening dan saldo di bank & $.346^{*}$ & 0.049 & Valid & \\
\hline 17. & Saya menabung dirumah & 0.338 & 0.054 & Tidak Valid & \\
\hline 18. & Saya mengikuti asuransi & 0.081 & 0.655 & Tidak Valid & \\
\hline 19. & $\begin{array}{l}\text { Saya menyisihkan sebagian uang untuk kebutuhan kesehatan dikala saya } \\
\text { sakit }\end{array}$ & $.518^{* *}$ & 0.002 & Valid & \\
\hline
\end{tabular}

\section{Self-Esteem}

\begin{tabular}{|c|c|c|c|c|c|}
\hline No. & Pernyataan & Pearson Correlation & Sig. (2-tailed) & Validitas & Reliabilitas \\
\hline 1. & $\begin{array}{l}\text { Saya dapat mengaktualisasikan diri saya terhadap } \\
\text { pengelolaan uang }\end{array}$ & $.438^{*}$ & 0.011 & Valid & \\
\hline 2. & Saya mengatur uang saku dengan cermat & $.680^{* *}$ & 0.000 & Valid & \\
\hline 3. & Saya mengelola pemasukan dengan bijak & $.620^{* *}$ & 0.000 & Valid & \\
\hline 4. & Saya mengelola pengeluaran dengan bijak & $.719^{* *}$ & 0.000 & Valid & \\
\hline 5. & $\begin{array}{l}\text { Saya menerima setiap masukan orang lain dalam } \\
\text { mengatur uang saku }\end{array}$ & $.711^{* *}$ & 0.000 & Valid & \\
\hline 6. & $\begin{array}{l}\text { Saya mensyukuri setiap uang saku yang diberikan } \\
\text { kepada saya }\end{array}$ & $.607^{* *}$ & 0.000 & Valid & \\
\hline 7. & $\begin{array}{l}\text { Saya mendengarkan cerita orang lain tentang bagaimana } \\
\text { mengatur uang saku }\end{array}$ & $.592^{* *}$ & 0.000 & Valid & Reliabel \\
\hline 8. & $\begin{array}{l}\text { Saya memanfaatkan uang saku yang diberikan untuk } \\
\text { pemenuhan kebutuhan dengan baik }\end{array}$ & $.803^{* *}$ & 0.000 & Valid & \\
\hline 9. & $\begin{array}{l}\text { Saya dapat mengatur uang saku yang diberikan dengan } \\
\text { efisien }\end{array}$ & $.748^{* *}$ & 0.000 & Valid & \\
\hline 10.* & Saya tidak dapat mengendalikan uang saku dengan baik & $.434^{*}$ & 0.012 & Valid & \\
\hline 11. & $\begin{array}{l}\text { Saya menerima masukan orang lain tentang cara } \\
\text { mengatur uang masuk saya }\end{array}$ & $.670^{* *}$ & 0.000 & Valid & \\
\hline 12. * & $\begin{array}{l}\text { Saya tidak suka menerima pendapat orang lain tentang } \\
\text { cara mengatur uang keluar saya }\end{array}$ & 0.312 & 0.077 & Valid & \\
\hline 13. & $\begin{array}{l}\text { Saya mendengarkan pendapat orang lain tentang cara } \\
\text { menabung yang baik }\end{array}$ & $.780^{* *}$ & 0.000 & Valid & \\
\hline 14. * & Saya tidak suka diberikan saran tentang mengelola uang & 0.302 & 0.088 & Tidak Valid & \\
\hline
\end{tabular}




\begin{tabular}{|c|c|c|c|c|}
\hline & saku & & & \\
\hline 15. & Saya suka mengelola uang apabila diberi hadiah & -0.129 & 0.474 & Valid \\
\hline 16. * & $\begin{array}{l}\text { Saya tidak akan mengelola uang dengan baik apabila } \\
\text { tidak ada rewardnya }\end{array}$ & $.466^{* *}$ & 0.006 & Tidak Valid \\
\hline 17.* & $\begin{array}{l}\text { Saya tidak suka mengatur keuangan dengan baik apabila } \\
\text { tidak diberi pujian }\end{array}$ & $.463^{* *}$ & 0.007 & Tidak Valid \\
\hline 18. & $\begin{array}{l}\text { Saya suka mengatur uang saku meskipun tidak diberi } \\
\text { sesuatu yang berharga/bernilai }\end{array}$ & $.527^{* *}$ & 0.002 & Tidak Valid \\
\hline 19. & $\begin{array}{l}\text { Saya merasa senang apabila terbiasa mengatur keuangan } \\
\text { dengan baik }\end{array}$ & $.689^{* *}$ & 0.000 & Valid \\
\hline 20. * & $\begin{array}{l}\text { Saya tidak merasa senang menggunakan uang saku untuk } \\
\text { pemenuhan keinginan }\end{array}$ & 0.202 & 0.260 & Tidak Valid \\
\hline 21. & $\begin{array}{l}\text { Saya merasa senang apabila uang saku digunakan dalam } \\
\text { pemenuhan kebutuhan }\end{array}$ & $.577^{* *}$ & 0.000 & Valid \\
\hline $22 * *$ & $\begin{array}{l}\text { Saya merasa sedih tidak bisa mengelola pengeluaran } \\
\text { dengan baik }\end{array}$ & 0.096 & 0.593 & Tidak Valid \\
\hline 23. & Saya tidak bisa membelanjakan uang saku dengan boros & $.633^{* *}$ & 0.000 & Valid \\
\hline 24.* & Saya membelanjakan uang saku sesuka hati saya & -0.125 & 0.488 & Valid \\
\hline 25. & $\begin{array}{l}\text { Saya hanya bisa membeli sesuatu yang } \\
\text { terjangkau/sebanding dengan uang yang saya miliki }\end{array}$ & $.765^{* *}$ & 0.000 & Valid \\
\hline 26. & $\begin{array}{l}\text { Saya mengetahui kapan waktu yang tepat untuk } \\
\text { membelanjakan uang saya }\end{array}$ & $.613^{* *}$ & 0.000 & Valid \\
\hline 27. & Saya menggunakan uang saku untuk berinfak & $.606^{* *}$ & 0.000 & Valid \\
\hline 28. & $\begin{array}{l}\text { Saya menggunakan uang saku untuk membantu } \\
\text { penggalangan dana sosial }\end{array}$ & $.630^{* *}$ & 0.000 & Valid \\
\hline 29. & $\begin{array}{l}\text { Saya menyisihkan sebagian uang saku untuk hal } \\
\text { bermasyarakat }\end{array}$ & $.476^{* *}$ & 0.005 & Valid \\
\hline 30. & Saya menyisihkan uang dirumah & $.673^{* *}$ & 0.000 & Valid \\
\hline 31. & $\begin{array}{l}\text { Saya menyisihkan sebagian uang saku untuk keadaan } \\
\text { mendesak }\end{array}$ & $.517^{* *}$ & 0.005 & Valid \\
\hline 32. & Saya memanfaatkan uang saku dengan baik & $.453^{* *}$ & 0.000 & Valid \\
\hline
\end{tabular}

\section{Self-Awareness}

\begin{tabular}{|c|c|c|c|c|c|}
\hline No. & Pernyataan & Pearson Correlation & Sig. (2-tailed) & Validitas & Reliabilitas \\
\hline 1. & Memusatkan perhatian terhadap pengolaan uang saku & $.646^{* *}$ & 0.000 & Valid & \\
\hline 2.* & Memusatkan perhatian terhadap pemasukan uang saku & $.502^{* *}$ & 0.003 & Valid & \\
\hline 3. & Memusatkan perhatian terhadap pengeluaran uang saku & $.765^{* *}$ & 0.000 & Valid & \\
\hline 4.* & Memusatkan perhatian terhadap cadangan uang saku & $.737^{* *}$ & 0.000 & Valid & \\
\hline 5. & $\begin{array}{l}\text { Tidak memperhatikan kesadaran diri terhadap } \\
\text { pengelolaan uang saku }\end{array}$ & $.741^{* *}$ & 0.000 & Valid & \\
\hline 6.* & $\begin{array}{l}\text { Memperhatikan kesadaran diri terhadap pemasukan uang } \\
\text { saku }\end{array}$ & $.861^{* *}$ & 0.000 & Valid & \\
\hline 7. & $\begin{array}{l}\text { Memperhatikan kesadaran diri terhadap pengeluaran } \\
\text { uang saku }\end{array}$ & 0.218 & 0.223 & Valid & Reliabel \\
\hline 8.* & $\begin{array}{l}\text { Memperhatikan kesadaran diri terhadap cadangan uang } \\
\text { saku }\end{array}$ & $.777^{* *}$ & 0.000 & Valid & \\
\hline 9. & $\begin{array}{l}\text { Saya membutuhkan orang tua dalam membantu } \\
\text { pengelolaan uang saku }\end{array}$ & $.746^{* *}$ & 0.000 & Valid & \\
\hline $10 .^{*}$ & $\begin{array}{l}\text { Saya membutuhkan dukungan teman dalam pengeluaran } \\
\text { uang saku }\end{array}$ & $.748^{* *}$ & 0.000 & Valid & \\
\hline 11. & $\begin{array}{l}\text { Saya memerlukan dukungan keluarga dalam pengeluaran } \\
\text { uang saku }\end{array}$ & 0.314 & 0.075 & Valid & \\
\hline 12. * & $\begin{array}{l}\text { Saya mencari tahu informasi tentang pengelolaan uang } \\
\text { saku di internet }\end{array}$ & $.403^{*}$ & 0.020 & Valid & \\
\hline 13. & $\begin{array}{l}\text { Saya bertanya tentang pengelolaan uang saku kepada } \\
\text { orang tua }\end{array}$ & $.450^{* * *}$ & 0.009 & Valid & \\
\hline
\end{tabular}


14. * Saya bertanya tentang pengelolaan uang saku kepada

$.459^{* *}$

0.007

Valid

15. Saya mengetahui bahwa apa yang kehidupan saya penuhi adalah cerminan diri saya

$.452^{* *}$

0.008

Valid

16. * Saya mengetahui uang saku yang saya kelola berdasarkan kemauan diri saya

17. Saya mengetahui uang saku yang saya kelola

$.516^{* *}$

0.002

Valid

berdasarkan kebutuhan diri saya

$.658^{* *}$

0.000

Valid 